\title{
MINAT POLITIK REMAJA TIONGHOA PEDESAAN
}

\author{
Bonar Hutapea ${ }^{1}$ \\ ${ }^{1}$ Fakultas Psikologi, Universitas Tarumanagara, Jakarta \\ Email:bonarh@fpsi.untar.ac.id
}

Masuk: 18-12-2020, revisi: 04-04-2021, diterima untuk diterbitkan: 30-04-2021

\begin{abstract}
Youth participation in politics is believed to have a significant and positive impact in the process of democratization.Family, age, and political trust factors are several factors related to adolescent interest in politics. However, teenagers mostly under 17 years old these days have less interest on politics. This study aimed at uncover political interest among Chinese-Indonesian adolescents, particularly those who live in rural area. By using simple survey and quantitative data, this study aims to uncover Chinese youth interest in politics as it relates to several relevant socio-psychological factors. Forty senior high school students who are Chinese descendants from Belinyu, Bangka Island were administered a questionnaire and demographic questions. Quantitative instruments use singleitem constructed in collaboration with the Department of Social Psychology, University of Macau, SAR. This study indicates that parents' political participation and political discussion in the family have significant positive relations with youth interest in politics and political discussion in the family is the strongest predictor. Unlike the two predictors, political trust does not relate to their political interest. These preliminary findings suggest that family may be very influential to civic engagement. Our results contribute to discussion in political psychology research to explain political socialization and political participation.
\end{abstract}

Keywords: Political interest, trust in government, political discussion, political participation, Chinese-Indonesian

\begin{abstract}
ABSTRAK
Partisipasi remaja dalam politik diyakini berdampak signifikan dan positif dalam proses demokratisasi. Akan tetapi, saat ini sebagian besar remaja terlebih yang belum berusia 17 tahun kurang memiliki minat dalam politik. Faktor keluarga, usia, dan political trust menjadi beberapa faktor yang berkaitan dengan minat remaja terhadap politik. Penelitian ini dimaksudkan untuk mengungkap ketertarikan terhadap politik di kalangan orang muda Tionghoa dan secara khusus, remaja yang tinggal di pedesaan. Dengan menggunakan survei sederhana dan data kuantitatif, riset ini bertujuan untuk mengungkap minat dalam politik yang berkaitan dengan beberapa faktor sosio-psikologis yang relevan. Empat puluh siswa sekolah lanjutan tingkat atas yang merupakan keturunan Tionghoa di Belinyu, Pulau Bangka diberikan kuesioner dan pertanyaan demografis. Instrumen kuantitatif menggunakan single-item yang dikonstruksi bekerja sama dengan Department of Social Psychology, University of Macau, SAR. Hasil penelitian ini menunjukkan bahwa partisipasi politik orang tua dan diskusi politik dalam keluarga memiliki hubungan positif dan signifikan dengan minat remaja dalam politik di mana diskusi politik dalam keluarga merupakan prediktor terkuat. Berbeda dengan dua prediktor tersebut, kepercayaan politik tidak terkait dengan minat partisipan terhadap politik. Temuan awal ini menunjukkan bahwa keluarga mungkin berperan terhadap keterlibatan remaja sebagai warga negara. Hasil penelitian ini berkontribusi pada diskusi dalam penelitian psikologi politik untuk menjelaskan sosialisasi politik dan partisipasi politik.
\end{abstract}

Kata kunci: Minat politik, kepercayaan pada pemerintah, diskusi politik, partisipasi politik, Tionghoa-Indonesia

\section{PENDAHULUAN}

\section{Latar Belakang}

Partisipasi orang muda dalam politik diyakini berdampak signifikan dan positif dalam proses demokratisasi. Akan tetapi, menurut berbagai penelitian, sebagian besar anak muda kurang tertarik dengan politik. Padahal, minat politik merupakan kunci pertahanan dan berkembangnya demokrasi (Russo \& Stattin, 2017). Hasil kajian Garcia-Albacete (2013) terhadap menurunnya keterlibatan orang muda dalam politik di negara-negara barat, disebabkan oleh: (a) meningkatnya sikap apatis terhadap lembaga politik; (b) tingkat ketidakpercayaan yang tinggi dan lemahnya dukungan untuk lembaga-lembaga demokrasi; dan (c) minat yang lebih rendah dalam urusan publik. 
Penelitian tentang perbedaan generasi dalam partisipasi politik menunjukkan bahwa minat merupakan prasyarat utama bagi warga negara yang aktif atau partisipatif dalam politik. Hal ini sejalan dengan pernyataan Roth et al. (2013), bahwa minat politik merupakan prakondisi bagi kewarganegaraan yang demokratis. Orang muda (remaja) berpartisipasi dengan cara yang sama dengan orang dewasa. Namun, terdapat perbedaan di antara keduanya yakni remaja lebih dipengaruhi oleh minat terhadap politik (Garcia-Albacete, 2013). Minat politik diartikan sebagai kehendak warga negara untuk memperhatikan fenomena politik dengan kemungkinan mengorbankan topik lain (Lupia \& Philpot, 2005).

Berdasarkan beberapa studi sebelumnya, Halvor (2016) menyatakan bahwa siswa yang memiliki minat politik tinggi cenderung lebih aktif secara politik. Meski demikian, masih belum diketahui dengan jelas mengenai minat terhadap politik dan perkembangannya sepanjang rentang kehidupan. Selain itu, belum diketahui dengan jelas alasan mengapa remaja berpartisipasi atau tidak berpartisipasi dalam aktivitas politik (White et al., 2000).

Mengacu pada sejumlah penelitian sebelumnya, keluarga berperan mendorong partisipasi politik (Ritter, 2008). Hal ini didukung oleh pernyataan Levinsen dan Yndigegn (2015), bahwa dari perspektif transmisi inter-generasi, pengaruh keluarga terus berlangsung dan sikap politik orang tua merupakan prediktor dari sikap anak-anaknya. Lebih khusus, Levinsen dan Yndigegn (2015) menyatakan bahwa keterlibatan anak muda dalam diskusi politik dengan orang tua merupakan bagian dari proses sosialisasi politik dan dapat dilihat sebagai aktivitas mempelajari keterampilan demokrasi mendasar. Mengingat keterlibatan dalam diskusi politik dengan keluarga cenderung mengarah kepada keterlibatan yang lebih tinggi dalam bentuk partisipasi politik, maka diduga akan berdampak pada meningkatnya minat politik.

Faktor lain yang diduga berkaitan dengan minat remaja terhadap politik adalah rasa percaya kepada pemerintah atau kepercayaan politik (political trust), yakni merujuk pada perasaan warga negara mengenai pemerintahnya (Citrin \& Stoker, 2018). Remaja, sebagai warga negara, serta siswa lanjutan dan menengah, memperoleh pelajaran di kelas dan di sekolah, diyakini telah mengetahui seluk-beluk masalah bangsa yang ditangani oleh pemerintah (Dassoneville et al., 2012; Saud, 2020; Yenuarizki et al., 2019; Feitosa, 2020). Dalam hal ini, rasa percaya dan tidak percaya, salah satunya terkait dengan hal penyelenggaraan pemerintahan yang bersih (clean governance) dan kebijakan pemerintahan (Christensen \& Lægreid, 2002; van der Brug \& van Praag, 2007).

Selain hal di atas, minat terhadap politik juga terkait dengan usia. Salah satunya adalah rendahnya minat politik mungkin disebabkan oleh kurangnya kesempatan untuk terlibat dalam proses politik bila berusia kurang dari 17 tahun. Hal ini sesuai dengan pernyataan White et al. (2000) bahwa batasan usia berkontribusi pada rendahnya minat politik.

Sejauh ini penelitian tentang minat dan keterlibatan politik, lebih banyak dilakukan pada kaum urban dan tidak secara jelas menyatakan adanya perbedaan minat politik antara remaja yang tinggal di kota dan di desa (Zhong, 2018). Meski demikian, patut diduga terdapat perbedaan keduanya dalam keterlibatan politik, salah satunya disebabkan perbedaan modal sosial. Warga desa diduga memiliki modal sosial yang lebih tinggi, disebabkan karakteristiknya yang berbeda dari warga kota, antara lain populasi yang lebih kecil, ikatan kekerabatan yang lebih kuat dan kecenderungan lebih lama tinggal pada suatu daerah (Shelton \& Garkovich, 2013). Dalam modal sosial yang tinggi, terkandung rasa percaya yang tinggi pada individu lain, lembaga dan anggota dewan yang mewakilinya. 
Dari uraian di atas, yang menyatakan bahwa keluarga berperan mendorong partisipasi politik yang didasari oleh minat politik (Korzenevica, 2016; Ritter, 2008). Penulis berasumsi bahwa peran keluarga dapat mengisi kekurangan kesempatan terlibat dalam proses politik yang disebabkan usia di bawah 17 tahun pada warga pedesaan.

\section{Rumusan Masalah}

Maksud dilakukannya penelitian ini adalah untuk mengetahui peran faktor keluarga dan kepercayaan kepada pemerintah dengan minat politik remaja Tionghoa di pedesaan. Penelitian ini diharapkan memberikan arah bagi riset survei yang akan dilakukan terkait partisipasi politik orang muda Tionghoa.

\section{METODE PENELITIAN}

Penelitian kuantitatif dengan desain survei dilakukan terhadap remaja etnik Tionghoa yang merupakan siswa-siswi sekolah lanjutan atas di Belinyu, Pulau Bangka, Provinsi Bangka-Belitung. Partisipan diberi penjelasan tentang penelitian ini di depan kelas. Penelitian ini bersifat pendahuluan sehingga dipilih teknik pengambilan sampel non-probability dan purposive. Oleh karena itu, hanya siswa dengan latar belakang etnis Tionghoa yang dapat berpartisipasi (sekurangkurang salah satu dari orang tua). Dari 42 partisipan, hanya 40 kuesioner yang dapat dilanjutkan untuk dianalisis. Adapun gambaran subjek penelitian dapat dilihat pada tabel 1:

Tabel 1. Karakteristik Demografis Partisipan $(n=40)$

\begin{tabular}{lll}
\hline \multicolumn{1}{c}{ Karakteristik } & $n$ & $\%$ \\
\hline Usia (dalam tahun) & 2 & 5,0 \\
Remaja awal (12-14) & 31 & 77,5 \\
Remaja madya (15-17) & 7 & 17,5 \\
$\quad$ Remaja akhir (18-20) & 1 & \\
\hline Agama & 9 & 2,5 \\
Islam & 3 & 22,5 \\
Kristen & 22 & 7,5 \\
Katolik & 5 & 55,0 \\
Buddha & & 12,5 \\
Konghucu & 16 & \\
\hline Jenis kelamin & 24 & 40,0 \\
Perempuan & & 60,0 \\
Laki-laki & 12 & 30,0 \\
Tingkat pendidikan ayah & 4 & 10,0 \\
Lulus SD & 20 & 50,0 \\
Lulus SLTP & 2 & 5,0 \\
Lulus SLTA & 2 & 5,0 \\
Diploma & & \\
Sarjana dan pascasarjana & 16 & 40,0 \\
Tingkat pendidikan ibu & 5 & 12,5 \\
Lulus SD & 15 & 37,5 \\
Lulus SLTP & 2 & 5,0 \\
Lulus SLTA & 2 & 5,0 \\
Diploma & & \\
Sarjana dan pascasarjana & &
\end{tabular}


Instrumen kuantitatif menggunakan single-item yang dikonstruksi bekerja sama dengan Department of Social Psychology, University of Macau, SAR sebagai bagian dari riset kolaborasi internasional yang melibatkan sampel berlatar belakang keturunan Tionghoa (ethnic Chinese) pada sejumlah negara di Asia (Bernardo et al., 2016). Instrumen berupa skala Likert (opsi 1-7), dengan item sebagai berikut: (a) seberapa tertarikkah Anda pada politik? dengan alternatif pilihan "sangat tidak tertarik" hingga "sangat tertarik" untuk mengukur minat politik; (b) seberapa percayakah Anda kepada pemerintah? dengan opsi "sangat tidak percaya" hingga "sangat percaya" untuk mengukur kepercayaan terhadap pemerintah; (c) partisipasi politik orang tua Anda berada pada tingkat mana dalam skala "sangat rendah" hingga "sangat tinggi" untuk mengukur partisipasi politik orang tua; dan (d) seberapa intensif dalam keluarga Anda berlangsung diskusi tentang masalah politik, dengan opsi "tidak pernah" hingga "selalu" untuk mengukur diskusi politik dalam keluarga.

Penggunaan item tunggal dalam penelitian bukanlah sesuatu yang tak lazim, bahkan dalam beberapa tahun terakhir mengalami peningkatan atas berbagai alasan. Hal ini dapat ditemukan dalam tinjauan hasil penelitian pada sejumlah pangkalan data termasuk PsycINFO, menunjukkan korelasi yang cukup tinggi dengan instrumen dengan multi-item (Ahmad et al., 2014). Hasil yang sama juga ditunjukkan oleh penelitian Leung dan Xu (2013) pada negara di Asia.

Dalam penelitian ini, dikumpulkan data-data demografi berupa usia, tingkat pendidikan orang tua, dan jenis kelamin. Namun, karena jumlah data yang terlalu jauh berbeda, hanya usia saja yang dapat dianalisis. Teknik analisis data yang dilakukan adalah Product Moment dari Pearson untuk menguji keterkaitan usia dalam uji inter-korelasi sebagaimana ditunjukkan dalam tabel 2 pada bagian berikutnya. Selama pengumpulan data, penulis tidak meminta persetujuan orang tua (parental consent) dengan pertimbangan bahwa remaja yang menjadi partisipan tidak tergolong sebagai kelompok di bawah umur (Weir, 2019).

\section{HASIL DAN PEMBAHASAN}

Tabel di bawah ini menunjukkan bahwa usia partisipan secara umum berada pada kategori remaja awal $(\mathrm{M}=14,97, \mathrm{SD}=0,92)$ meskipun dalam karakteristik demografis mayoritas partisipan berada (modus) pada interval usia 15-17 tahun. Hal ini dapat dipahami mengingat partisipan mayoritas merupakan siswa kelas sepuluh pada sekolah lanjutan atas. Adapun nilai rata-rata, standar deviasi dan hasil uji inter-korelasi variabel dapat dilihat pada tabel 2.

Tabel 2. Nilai Rata-rata, Standar Deviasi dan Inter-korelasi menggunakan Product Moment

\begin{tabular}{|c|c|c|c|c|c|c|c|c|}
\hline \multicolumn{9}{|c|}{ Pearson $(n=40)$} \\
\hline \multicolumn{2}{|c|}{ Variabel } & M & SD & 1 & 2 & 3 & 4 & 5 \\
\hline 1. & 1. Usia & 14,97 & 0,920 & - & 0,06 & 0,02 & 0,04 & 0,04 \\
\hline 2. & 2. Partisipasi politik orang tua & 4,27 & 1,894 & & - & $0,60^{* *}$ & $0,32^{*}$ & $0,35^{*}$ \\
\hline 3. & 3. Minat politik & 3,07 & 1,760 & & & - & $0,49^{* *}$ & $0,76^{* *}$ \\
\hline $\begin{array}{l}4 . \\
\text { pe }\end{array}$ & $\begin{array}{l}\text { 4. Kepercayaan kepada } \\
\text { tah }\end{array}$ & 4,23 & 1,441 & & & & - & $0,44 * *$ \\
\hline 5. & 5. Diskusi politik dalam keluarga & 3,00 & 1,881 & & & & & - \\
\hline
\end{tabular}


Dari tabel di atas diketahui bahwa partisipasi politik orang tua, sebagaimana dipersepsikan oleh partisipan, berada pada kategori tinggi $(M=4,27, S D=1,89)$. Dalam hal ini, partisipan menilai orang tua masing-masing menunjukkan keterlibatan dan partisipasi terkait politik, antara lain menggunakan hak pilih dalam pemilihan kepala daerah dan pemilihan umum, menghadiri kampanye kandidat politik, dan lain sebagainya. Dengan demikian, kepercayaan kepada pemerintah (presiden, menteri/kabinet, kepolisian (polri), tentara (TNI)) tergolong tinggi $(\mathrm{M}=4,23$, $\mathrm{SD}=1,44)$. Hal ini dapat diartikan bahwa penyelenggaraan pemerintahan berlangsung dengan baik, pemerintahan dijalankan mengikuti tata kelola yang baik (good governance) dan aparatur pemerintahan dapat dipercaya menjalankan tugas, wewenang, tanggung jawabnya dengan baik sebagai kinerja pemerintah (government performance).

Ketertarikan partisipan terhadap politik dan diskusi politik dalam keluarga tergolong rendah $(\mathrm{M}=3,07, \mathrm{SD}=1,76)$. Hal ini dapat diartikan bahwa remaja yang menjadi partisipan penelitian kurang berminat dengan masalah-masalah terkait politik dan kurang menunjukkan upaya untuk mengetahui informasi terkini tentang politik. Begitu pula halnya dengan pengalaman membicarakan masalah politik dengan orang tua dan anggota keluarga lainnya tergolong kurang $(\mathrm{M}=3,00, \mathrm{SD}=1,88)$, artinya partisipan kurang mendapatkan klarifikasi dari orang tua dan/atau anggota keluarga lainnya tentang suatu masalah yang berkaitan dengan politik, atau ketika remaja tidak hadir dan terlibat dalam pembicaraan yang berhubungan dengan politik. Selanjutnya, untuk mengetahui kontribusi relatif dan kontribusi efektif variabel-variabel yang diidentifikasi sebagai prediktor terhadap kriteria, dilakukan analisis regresi ganda dan hasilnya dapat dilihat pada tabel di bawah ini:

Tabel 3. Hasil Analisis Regresi $(n=40)$

\begin{tabular}{llllll}
\hline Variabel sebagai prediktor & $\mathbf{B}$ & SE $\mathbf{B}$ & $\boldsymbol{\beta}$ & $\mathbf{R}^{2}$ & $\mathbf{\Delta R}^{\mathbf{2}}$ \\
\hline Konstanta & 1,47 & 0,89 & & $0,70^{* *}$ & $0,66^{* *}$ \\
Partisipasi politik orang tua & 0,26 & 0,07 & $0,39^{*}$ & & \\
Kepercayaan kepada pemerintah & 0,05 & 0,04 & 0,15 & & \\
Diskusi politik dalam keluarga & 0,81 & 0,19 & $0,49^{* *}$ & & \\
\hline
\end{tabular}

Dalam penelitian ini diketahui bahwa diskusi politik dalam keluarga berperan signifikan dan positif terhadap ketertarikan pada politik $(B=0,81, \beta=0,49, p<0,001)$. Hal ini dapat dimaknai bahwa keterpaparan terhadap informasi tentang politik melalui diskusi di rumah dengan orang tua, selain dari sumber lainnya, akan membangkitkan minat politik (White et al., 2000). Pengalaman dibesarkan dalam keluarga di mana terdapat diskusi politik dalam konteks diskusi umum dengan orang tua dan anggota keluarga lainnya, misalnya ketika remaja mencari klarifikasi tentang suatu masalah yang berkaitan dengan politik, atau ketika orang muda hadir saat orang tua mereka menonton berita, atau program lain yang berhubungan dengan politik. Dalam hal ini, orang tua, saudara kandung atau anggota keluarga lainnya merupakan stimulan minat politik remaja. Hal lain yang dapat menjelaskan mengapa diskusi politik dalam keluarga berkaitan erat dengan minat politik remaja adalah bahwa, berbeda dengan ruang publik, keluarga ditandai dengan ikatan emosional yang kuat (Levinsen \& Yndigegn, 2015). Oleh karena itu, remaja akan lebih terlibat dan lebih menunjukkan perhatian dalam diskusi.

Temuan penelitian ini mendukung the communication mediation model (CMM) tentang pentingnya komunikasi, salah satunya dalam keluarga, dalam upaya pengembangan kompetensi dan motivasi demokratis warga muda agar terlibat dalam politik (Shehata \& Amnå, 2019). Dalam hal ini, minat politik remaja Tionghoa berkembang terkait dengan praktek komunikatif yang dibentuk oleh norma sosial dan perilaku dalam keluarga remaja tersebut. Selain itu, dapat 
dijelaskan pula melalui teori pembelajaran sosial (social learning theory), yakni lingkungan rumah memberikan kesempatan belajar bagi remaja (Shehata \& Amnå, 2019). Dengan dikelilingi oleh orang-orang yang menghargai informasi tentang politik, sebagai warga muda mereka lebih sering terpapar topik-topik politik, sehingga memiliki kesempatan lebih besar untuk bertemu, mengalami, dan mengeksplorasi masalah publik, argumen politik, dan perbedaan. Dengan belajar lebih banyak dan menjadi lebih sadar politik, mereka menjadi lebih mampu memahami relevansi politik dengan kehidupan mereka sendiri. Pada gilirannya, inilah faktor yang terkait dengan perkembangan minat politik.

Penelitian ini juga menemukan bahwa partisipasi politik orang tua berperan penting terhadap ketertarikan partisipan pada politik $(B=0,26, \beta=0,39, p<0,05)$, bersamaan dengan peran diskusi politik dalam keluarga. Temuan ini mendukung pernyataan Print (2007) dalam menjawab bagaimana siswa belajar tentang demokrasi dan bagaimana mereka menjadi lebih terlibat, yakni disebabkan peran orang tua sebagai sumber informasi terpenting. Dalam hal ini, orang tua sebagai sumber utama sosialisasi politik berpengaruh pada pembelajaran politik dan demokrasi bertindak sebagai model peran (role modelling) dan diskusi. Temuan penelitian ini juga mendukung teori pembelajaran (learning theory) dalam menjelaskan sosialisasi politik, yakni bagaimana sikap, nilai, dan perilaku ditularkan ke warga negara (Shehata \& Amnå, 2019). Remaja Tionghoa memiliki ketertarikan kepada politik karena ditularkan orang tua melalui partisipasi aktif dalam politik. Selain itu, menurut White et al. (2000), berpartisipasi politik antara lain dengan menandatangani petisi, demonstrasi dan bentuk partisipasi politik lainnya, orang tua mendorong anak muda untuk terlibat secara politik, dan pada gilirannya membuat anak muda semakin berminat pada politik.

Salah satu temuan menarik dalam penelitian ini adalah, rasa percaya kepada pemerintah tidak menjadi prediktor terhadap ketertarikan pada politik. Hal ini seperti mengkonfirmasi temuan Scheidegger dan Staerklé (2011) di Swiss bahwa minat politik sangat lemah keterkaitannya, bahkan sangat mungkin tidak terkait dengan kepercayaan politik.

Salah satu argumen yang dapat diajukan untuk temuan ini adalah bahwa rendahnya kepercayaan kepada institusi politik mungkin juga merupakan cerminan dari politik cerdas dan luaran yang diharapkan dari demokrasi. Hal ini sesuai dengan pandangan bahwa kepercayaan politik itu seperti pedang bermata dua, yaitu: demokrasi menuntut adanya kepercayaan namun juga menganggap bahwa warga negara aktif dan waspada dengan bersikap skeptis yang wajar terhadap pemerintah dan kehendak (politik) pemerintah. Apabila diperlukan, sikap skeptis itu bisa menguat lalu meniadakan rasa percaya kemudian melakukan kontrol terhadap pemerintah (Catterberg \& Moreno, 2006). Selain itu, menurut Christensen dan Lægreid (2002), opini publik tentang lembaga pemerintah seringkali tidak konsisten bahkan ambivalen, dan lebih dicirikan oleh kompleksitas kognitif daripada konsistensi. Bahkan, erosi kepercayaan terutama terjadi pada individu terdidik, diperkuat dengan temuan penelitian yang menunjukkan korelasi negatif antara kepercayaan politik dan minat politik (Citrin \& Stoker, 2018; Peterson et al., 2016; van der Brug \& van Praag, 2007).

Penjelasan lain juga menunjukkan bahwa sangat dimungkinkan seseorang mencermati persoalan terkait politik, namun tidak menunjukkan ketertarikan pada politik. Hal ini sejalan dengan pernyataan White et al. (2000), bahwa meskipun seseorang seringkali tidak menilai dirinya tertarik dengan politik, namun menunjukkan keprihatinan dengan isu-isu yang menjadi agenda utama pemerintah. Hal ini didukung oleh penjelasan dengan menggunakan pendekatan kepentingan selektif yang menyatakan bahwa minat individu itu bersifat selektif. Oleh karena itu, orang yang menunjukkan minat dalam politik adalah seseorang yang benar-benar menyukai politik, cenderung 
lebih partisan, dan lebih terlibat secara politik. Dalam hal ini, remaja yang menjadi partisipan penelitian ini dapat diyakini tidak memenuhi kriteria tersebut.

Namun, alasan yang paling masuk akal, menurut penulis adalah bahwa minat terhadap politik menurut White et al. (2000), tidak bisa dilepaskan dari relevansi perkembangan politik dengan kehidupan pribadi individu. Dalam hal ini, remaja Tionghoa yang menjadi partisipan penelitian merupakan siswa sekolah lanjutan atas, yang sangat mungkin lebih berfokus pada sekolah dan kemungkinan rencana melanjutkan pendidikan ke perguruan tinggi.

Dalam penelitian ini ditemukan bahwa minat politik remaja Tionghoa tergolong rendah, meskipun terkait erat dengan persepsi tentang partisipasi politik orang tua dan percakapan terkait politik di mana kedua variabel berkontribusi sebesar 70 persen. Artinya, 30 persen lainnya disumbang oleh faktor lain yang belum dilibatkan dalam penelitian ini. Salah satu faktor yang layak dipertimbangkan untuk menjelaskan rendahnya minat politik remaja Tionghoa adalah pandangan tentang diskriminasi. Sudah bukan rahasia bahwa dalam konteks situasi politik dan sejarah di Indonesia, etnis Tionghoa mengalami diskriminasi (Eriyanti, 2006; Tan, 2005), meski dalam masa reformasi hingga saat ini pengalaman partisipan tidak sama dengan generasi terdahulu, sangat dimungkinkan mengetahuinya melalui "sosialisasi" dari generasi sebelumnya (Hutapea \& Dewi, 2020), terutama orang tua. Menurut White et al. (2000), semua kelompok umur menganggap masalah diskriminasi terhadap kelompok tertentu di masyarakat sebagai hal yang penting untuk diangkat atau dibahas. Selain itu, faktor personal seperti belief dan nilai yang berinteraksi dengan kondisi keuangan dan faktor eksternal lainnya dapat dipertimbangkan diteliti karena dianggap akan menentukan bagaimana remaja mengkonseptualisasikan politik dan pada gilirannya memengaruhi perilaku terkait politik dan peristiwa perjumpaan dalam hidup sehari-hari (everyday life encounter events) (Stattin et al., 2017; White et al., 2000).

Secara khusus, faktor sekolah juga patut dipertimbangkan untuk dilibatkan, mengingat partisipan penelitian ini berstatus pelajar. Menurut Garcia-Albacete (2013), bersama dengan keluarga, sekolah dianggap berperan sebagai agen sosialisasi politik. Pendidikan kewarganegaraan di sekolah merupakan anteseden keterlibatan politik. Oleh karena itu, sekolah dapat dianggap berperan dalam mendorong minat politik siswa dan peluang menjangkau siswa yang tidak mendapatkan sosialisasi politik dalam keluarganya selain mengingat karakteristik remaja bahwa mereka lebih mudah dipengaruhi hal lain di luar keluarga. Hal ini didukung hasil penelitian Stadelmann-Steffen dan Sulzer (2018) bahwa pendidikan politik berbasis kelas tampaknya tidak mengkompensasi kurangnya sosialisasi politik di rumah, tetapi cenderung mempengaruhi siswa dengan orang tua yang sangat tertarik secara politik. Selain itu, faktor psiko-sosial lain seperti penggunaan media sosial (Holt et al., 2013) juga sebaiknya mendapat perhatian tersendiri mengingat remaja dan dewasa muda dianggap lebih cenderung aktif dan komunikatif melalui jejaring internet, sekaligus menguji temuan Richey dan Zhu (2015) yang menyimpulkan sebaliknya.

Penelitian ini mengandung sejumlah keterbatasan, di antaranya adalah jumlah partisipan yang masih sangat sedikit bila dibandingkan jumlah generasi millennial Tionghoa di daerah pedesaan; begitu pula dengan teknik pengambilan sampel yang belum mempertimbangkan banyak variasi dan sumbernya. Oleh karena itu, hasil penelitian ini tidak dapat digeneralisasikan kepada secara luas kepada populasi. 
Secara khusus, terkait instrumen pengumpulan data dalam penelitian ini yang menggunakan item tunggal untuk setiap variabel, meski dari sudut pandang psikometri tidak diketahui dengan jelas apakah item tunggal atau harus item berpasangan dengan makna yang berlawanan yang lebih baik untuk dioperasionalkan mengukur persetujuan (acquiescence) sebagai indikasi sikap, sebagaimana dinyatakan (Konstabel et al., 2017), penulis menyarankan penggunaan instrumen lain layak dipertimbangkan dalam riset lanjutan.

\section{KESIMPULAN DAN SARAN}

Penelitian ini menunjukkan bahwa keluarga merupakan prediktor yang kuat terhadap ketertarikan remaja terhadap politik. Implikasi praktis dari temuan penelitian ini antara lain adalah perlu mengintensifkan diskusi politik dalam keluarga dan perlu menjaga partisipasi politik orang tua yang tergolong tinggi agar ketertarikan terhadap politik dapat menguat. Secara khusus, bagaimana orang tua dapat melibatkan anak dalam pengetahuan dan nilai sedemikian rupa sehingga termotivasi dan percaya diri untuk berminat terhadap politik dan melibatkan diri dalam permasalahan kebangsaan merupakan fungsi dan peran yang amat penting sebagai agen sosialisasi politik.

Adapun implikasi teoritis dari penelitian ini adalah perlu dilakukan penelitian lanjutan dengan mempertimbangkan penerapan riset kualitatif untuk mendapatkan pemahaman yang lebih mendalam maupun riset kuantitatif yang melibatkan sampel lebih besar dan mempertimbangkan variabel psiko-sosial lain yang belum dilibatkan dalam penelitian ini.

Mengingat adanya kekhawatiran tentang terputusnya hubungan kaum muda dari politik dan dampaknya pada demokrasi di masa depan, dibutuhkan pemahaman secara lebih mendalam tentang masalah minat politik. Terlepas dari keterbatasannya, penelitian pendahuluan ini telah berkontribusi terhadap khazanah kepustakaan terkait minat politik, sosialisasi politik, dan partisipasi politik khususnya pada kaum muda yang dirasakan semakin penting dalam konteks proses demokratisasi di Indonesia.

\section{Ucapan Terima Kasih (Acknowledgement)}

Penulis menyampaikan terimakasih kepada Direktorat Riset dan Pengabdian Kepada Masyarakat (DRPM), Kementerian Riset dan Teknologi/Badan Riset dan Inovasi Nasional (Kemenristek/BRIN) untuk dukungan dana penelitian melalui Hibah PDUPT bagi penulis (No.855-SPK-DIR.PPKM/UNTAR/V/2019). Penulis juga berterimakasih kepada Saudara Chandra Susanto, atas bantuannya yang sangat berharga sebagai penghubung dengan pihak terkait di Belinyu dalam rangka pengurusan perizinan dan juga membantu pengumpulan data.

\section{REFERENSI}

Ahmad, F., Jhajj, A. K., Stewart, D. E., Burghardt, M., \& Bierman, A. S. (2014). Single item measures of self-rated mental health: A scoping review. BMC Health Services Research, 14(1), 1-11. https://doi.org/10.1186/1472-6963-14-398

Bernardo, A. B. I., Salanga, M. G. C., Tjipto, S., Hutapea, B., Yeung, S. S., \& Khan, A. (2016). Contrasting lay theories of Polyculturalism and Multiculturalism: Associations with essentialist beliefs of race in six Asian cultural groups. Cross-Cultural Research, 50(3). https://doi.org/10.1177/1069397116641895

Catterberg, G., \& Moreno, A. (2006). The individual bases of political trust: Trends in new and established democracies. International Journal of Public Opinion Research, 18(1), 31-48. https://doi.org/10.1093/ijpor/edh081 
Christensen, T., \& Lægreid, P. (2002). Trust in government: The relative importance of service satisfaction, political factors, and demography. In Working Paper 18-2002.

Citrin, J., \& Stoker, L. (2018). Political trust in a cynical age. Annual Review of Political Science, 21, 49-70. https://doi.org/10.1146/annurev-polisci-050316-092550

Dassoneville, R., Quintelier, E., Hooghe, M., \& Claes, E. (2012). The impact of civic education on political attitudes and behavior: A two-year panel study among Belgian late adolescents. Applied Developmental Science, 16(3), 140-150.

Eriyanti, F. (2006). Dinamika posisi identitas etnis Tionghoa dalam tinjauan Teori Identitas Sosial. Demokrasi, 5(1), 23-34.

Feitosa, F. (2020). Does civic education foster civic duty? A systematic cross-country analysis of the effect of three forms of civic education on the sense of civic duty to vote. Canadian Journal of Political Science, 53(4), 887-901. https://doi.org/10.1017/S0008423920000669

Garcia-Albacete, G. M. (2013). Promoting political interest in school: The role of civic education. In S. Abenschön (Ed.), Growing into Politics: Contexts and Timing of Political Socialisation (Issue October 2002, pp. 91-113). ECPR Press.

Halvor, C. D. B. (2016). Increasing social work students' political interest and efficacy. Journal of Policy Practice, 15(4), 289-313. https://doi.org/10.1080/15588742.2015.1081578

Holt, K., Shehata, A., Strömbäck, J., \& Ljungberg, E. (2013). Age and the effects of news media attention and social media use on political interest and participation: Do social media function as leveller? European Journal of Communication, 28(1), 19-34. https://doi.org/10.1177/0267323112465369

Hutapea, B., \& Dewi, F. I. R. (2020). Identitas diri nasional generasi millennial Tionghoa: Studi pendahuluan. Seri Seminar Nasional Universitas Tarumanagara (Serina Untar), 2 Desember.

Konstabel, K., Lönnqvist, J. E., Leikas, S., Velázquez, R. G., Qin, H., Verkasalo, M., \& Walkowitz, G. (2017). Measuring single constructs by single items: Constructing an even shorter version of the "Short Five" personality inventory. PLOS ONE, 12(8), 1-18. https://doi.org/10.1371/journal.pone.0182714

Korzenevica, M. (2016). Young people navigating political engagement through post-war instability and mobility: A case from rural Nepal. Geoforum, 74, 19-28. https://doi.org/10.1016/j.geoforum.2016.05.006

Leung, S. O., \& Xu, M. L. (2013). Single-Item Measures for subjective academic performance, self-esteem, and socioeconomic status. Journal of Social Service Research, 39(4), 511520. https://doi.org/10.1080/01488376.2013.794757

Levinsen, K., \& Yndigegn, C. (2015). Political discussions with family and friends: Exploring the impact of political distance. Sociological Review, 63(S2), 72-91. https://doi.org/10.1111/1467-954X.12263

Lupia, A., \& Philpot, T. S. (2005). Views from inside the net: How websites affect young adults' political interest. Journal of Politics, 67(4), 1122-1142. https://doi.org/10.1111/j.14682508.2005.00353.x

Peterson, D. A. M., Saunders, K. L., McClurg, S. D., \& Miller, J. M. (2016). Macrointerest: The public as attentive Gods of Vengeance but lazy Gods of Reward (with Apologies to V.O. Key). Working Paper, 2002, 1-29. 
Print, M. (2007). Citizenship education and youth participation in democracy. British Journal of Educational Studies, 55(3), 325-345. https://doi.org/10.1111/j.1467-8527.2007.00382.x

Richey, S., \& Zhu, J. (2015). Internet access does not improve political interest, efficacy, and knowledge for late adopters. Political Communication, 32(3), 396-413. https://doi.org/10.1080/10584609.2014.944324

Ritter, J. A. (2008). A national study predicting licensed social workers' levels of political participation: The role of resources, psychological engagement, and recruitment networks. Social Work, 53(4), 347-357. https://doi.org/10.1093/sw/53.4.347

Roth, W.-M., Lee, Y.-J., \& Hsu, P.-L. (2013). Homemade citizens: The development of political interest during adolescence and young adulthood. Acta Politica, 48(1), 92-116. https://doi.org/10.1080/01425690701737481

Russo, S., \& Stattin, H. (2017). Stability and change in youths' political interest. Social Indicators Research, 132(2), 643-658. https://doi.org/10.1007/s11205-016-1302-9

Saud, M. (2020). Civic engagement, youth socialisation and participation in public spheres in Indonesia. Children and Youth Services Review, 119(October), 105669. https://doi.org/10.1016/j.childyouth.2020.105669

Scheidegger, R., \& Staerklé, C. (2011). Political trust and distrust in Switzerland: A normative analysis. Swiss Political Science Review, 17(2), 164-187. https://doi.org/10.1111/j.16626370.2011.02010.x

Shehata, A., \& Amnå, E. (2019). The development of political interest among adolescents: A communication mediation approach using five waves of panel data. Communication Research, 46(8), 1055-1077. https://doi.org/10.1177/0093650217714360

Shelton, C., \& Garkovich, L. (2013). Assessing factors influencing political engagement in local communities. Community Development, 469-491. https://doi.org/10.1080/15575330.2013.822401

Stadelmann-Steffen, I., \& Sulzer, L. (2018). Just another brick in the wall? The relationship between classroom-based political education and the political interest of young adults in Switzerland. Journal of Youth Studies, 21(4), 552-575. https://doi.org/10.1080/13676261.2017.1395832

Stattin, H., Hussein, O., özdemir, M., \& Russo, S. (2017). Why do some adolescents encounter everyday events that increase their civic interest whereas others do not? Developmental Psychology, 53(2), 306-318. https://doi.org/10.1037/dev0000192

Tan, M. G. (2005). Ethnic Chinese in Indonesia. In S. I. Ember M., Ember C.R. (Ed.), Encyclopedia of Diasporas (pp. 795-808). Springer. https://doi.org/10.1007/978-0-38729904-4_82

van der Brug, W., \& van Praag, P. (2007). Erosion of political trust in the Netherlands: Structural or temporarily? A research note. Acta Politica, 42(4), 443-458. https://doi.org/10.1057/palgrave.ap.5500203

Weir, K. (2019, February). Studying adolescents without parents' consent: A new APA resolution supports mature minors' participation in research without parental permission. APA. https://www.apa.org/monitor/2019/02/parents-consent

White, C., Bruce, S., \& Ritchie, J. (2000). Young people's politics: Political interest and engagement amongst 14-24 year olds. Joseph Rowntree Foundation. 
Yenuarizki, Y., Febriana, K., \& Febianisari, N. (2019, October 30). Listening to the youth: Are we all ready?

Thejakartapost.Com. https://www.thejakartapost.com/academia/2019/10/30/listening-to-the-youth-are-we-allready.html

Zhong, Y. (2018). Political culture and participation in urban China (1st ed.). Palgrave Macmillan UK. https://doi.org/10.1007/978-981-10-6268-1 